\title{
Exploring Innovation Based on Service User Complaints to Increase Satisfaction
}

\author{
Rustan Amarullah ${ }^{*} \quad$ Maria A.P. Sari Fani Heru Wismono Kemal Hidayah \\ Wildan Lutfi A Mayahayati Kusumaningrum \\ Center for Training and Development and Decentralization and Regional Autonomy Studies (Puslatbang \\ KDOD), National Institute of Public Administration, 75124 Samarinda, Indonesia
}

\begin{abstract}
Increasing service user satisfaction levels is a goal for public service providers. Service user satisfaction surveys are often conducted to describe the level of service user satisfaction that services provided. However, service providers are less able to utilize the results of the surveys to conducting innovation or breakthroughs to improve service user satisfaction. This study used an explorative approach to analyze the level of satisfaction for service users in four public health centers (Puskesmas) in Bontang City, Indonesia. The method used was two stages survey of 1,449 respondents throughout 2019. The complaint in the first survey was the basis for innovating improvements in public services by using the concept of rapid innovation. The results showed that with the short-term innovations that had been implemented, there had been a significant increase in public satisfaction with the services of the Puskesmas.
\end{abstract}

Keywords: customer satisfaction; innovation; public service; public health centers

DOI: $10.7176 / \mathrm{EJBM} / 13-16-08$

Publication date:August $31^{\text {st }} 2021$

\section{Introduction}

The implementation of public services conducted by the government in various service sectors, especially to meet the civil rights and basic needs of the community, the performance is still not as expected. Dwiyanto's research (2002-2015) showed that public bureaucracy in Indonesia at that time still did not provide efficient, fair, responsive and accountable public services. At that time the government tended to develop into an inefficient institution and did not care about the public interest. This is, among others, seen from the many complaints of the community and the business world. The poor performance of public services is partly due to the lack of transparency and accountability in the implementation of public services.

From the Ombudsman's Annual Report in 2020, complaints or public reports related to public servants that have been handled and completed throughout 2020 reached 7.204 reports. From the data, local governments were reported the most by society about public services as much as 39.59 percent (Ombusdman RI, 2020).

This condition needs attention, where public services should be evaluated periodically. Customer satisfaction surveys can be a medium for improving public services. The survey was also conducted with the aim that the participation of the public as service users is able to assess the performance of service providers and encourage the improvement of the quality of public services itself. At least the satisfactory survey results can be used as a monitoring and evaluation tool for service provider leaders to be decision-making materials to improve services to the community. Thus, the principle of New Public Service (NPS) can be applied in public organizations and still pay attention to community service (Putra, 2020).

Besides to know how customers perceive the services that have been provided, satisfaction surveys can also be used by the government as a source of innovation in public services (Simmons \& Brennan, 2017). Public service providers should be able to assess the cause of the decline in the quality of services complained by the community, whether it is only needed a simple service recovery or whether it is necessary to redesign the service. If a redesign of the service is needed to rectify customer complaints, then the presence of innovation is indispensable.

Some studies related to the satisfaction of public service users in the scope of local government in Indonesia tend to only show the results or value of public satisfaction, such as Savitri \& Armando (2019) and Fahamsyah (2018). Relatively the research is still limited to the complaints of service users and use it as a basis for following-up to the results of public satisfaction.

From the previous research, it can also be known that the knowledge and experience of the community getting a service can be investigated from the management of complaints (Siregar et.al., 2017; Hidayati \& Novani, 2015). Due to the limited follow-up of complaint resolution, innovation needs to be found as one of the customer-based complaint solutions. Nowadays, the research has been widely associated with the improvement of the complaints system as a public service innovation, but the research that changes various public complaints as innovations that can be presented by service providers is still limited. Public complaints will become innovation input and process to produce public service innovation output. Then, it will provide better public service improvement. Organizations need to invest innovations to improve the quality of services perceived by 
customers (Yaşlioğlu et.al., 2013). Therefore, this study tries to fill the existing gaps. Further discussion related to innovations produced based on community complaints, so this research is important to be done today.

This research will be focused on public health services (Puskesmas) with the consideration that Puskesmas is a basic need and most influential for the community and they need the best service in Puskesmas. Also, Puskesmas needs a foundation or reference in the management, improvement and provision of optimal public services for people. The research question that will be reviewed in this study are, (1) What is the level of community satisfaction towards Puskesmas services? (2) What complaints arise regarding the services provided by Puskesmas? and (3) What are innovative ideas to improve public services to be implemented and how successful is the application of such innovations to the satisfaction of the community?

\section{Literature Review}

\subsection{New Public Management (NPS) approach and customer focus for optimal satisfaction}

In today's competitive world, service providers need to continuously improve customer satisfaction because it is the determining factor of the superiority of the service provider's position in competing (Parobek et.al, 2015). Also, the service provider needs to explore the source of customer satisfaction information by understanding the customer's feelings after receiving the service (Yoon, 2010). So far, the service provider has known that the customer will demand a minimum balanced proof of the sacrifice given (Mouwen; 2:2015). Every customer has a certain expectation of each sacrifice. This level of customer satisfaction depends heavily on the quality of service provided by the service provider unit. The quality of service is basically a conformity between the perceived service (perceived service) with customer expectations (customer expectation), where the suitability of both will show the level of customer satisfaction. So, it can be said that if the level of customer satisfaction can be known, it will also be known the quality of services provided by service providers (Khan, Batool, Scholar, \& Hussain; 2015:1040).

At first customer satisfaction is a critical point of concern in the business sector. This is because a company must understand exactly what their customers feel about the services that have been provided. That way, they can maintain customer loyalty, double the profits and improve the company's competitiveness (Ghotbabadi, Feiz, Baharun; 2015:268).

As for the public sector, customer satisfaction relates to the concept of customer orientation initiated by the private sector (Chatzoglou, Chatzoudes, Vraimaki \& Diamantidis; 2013:586). This concept emphasizes the fulfillment of customer needs, which leads to improved organizational performance (Huang \& Dastmalchian; 2006:362). Therefore, although not profit-oriented, in reality the concept of customer satisfaction in the public sector becomes very relevant. This is because the input of the community can be used as input for government organizations in improving their performance (Akinboade, Kinfack, \& Mokwena; 2012:184).

On this occasion, we also need to see that there has been a paradigm shift in public services. The relevant paradigm and discussed in this paper is the New Public Service (NPS) paradigm. From NPS point of view, customers become the central point for service providers. So, the role of service providers is to help customers articulate and find their desire to receive services rather than just controlling the wishes of customers (Dendhardt \& Denhardt, 2000).

Solong (2017) expressed the view that the ability of service providers to respond to customer wishes will refer to how quickly problems with customer service results can be resolved. The response will be shown to customers through programs and actions of any service changes that have been done to improve services towards a more optimal quality of service. So that the seriousness of the service provider makes the customer as the center of attention of the service by providing alternative service improvement solutions to be the main value that will improve the quality of service.

Therefore, paying special attention to customer satisfaction becomes an inevitability, no exception in the healthcare sector. This is because currently, government hospitals and health centers must compete with the private sector in providing health services. Even some research results in some countries show that people are more satisfied with private hospital services than government hospitals (Ahmed, Tarique \& Arif, 2017; Bamfo, 2017; Irfan \&Ijaz, 2011). If government hospitals do not pay attention to customer satisfaction, then it is certain that very few patients will choose to seek treatment there, anything will be their last option (Javed \& Ilyas; 2018:2).

\subsection{The Importance of innovating in public services of health}

According to Delafrooz et al., a service innovation can make consumers very satisfied with the service provided by the company. In its implementation this happens because the company is able to present something new in the provision of services that can be seen from the technology used to serve consumers, improved interaction with consumers needed to serve consumers, improved interaction with consumers needed to maintain communication with consumers and the development of services provided to consumers (Antanegoro, Surya, \& Sanusi, 2017).

Innovation to improve the quality of public services has many factors to consider. This is because efforts to 
improve the quality of service have a significant impact on the overall culture of the organization. Factors in improving the quality of service according to Tjiptono \& Chandra (2005) include: 1) Identify the main determinants of service quality. Service providers need to understand the characteristics of the services provided so that it will be easy to assess a service. 2) Manage customer expectations. What has been promised to customers becomes the focus of the fulfillment of services from the service provider. 3) Manage proof of service quality. Customers tend to pay attention and perceive what they feel and experience from a service. So, service providers need to capture and manage customers' taste and experience through a certain measuring instrument in order to prove how quality the service is provided. 4) Provide knowledge to consumers about the services provided. Service providers are able to convey the necessary information from the services provided to customers by means of appropriate communication and information media. 5) Develop a culture of quality. Quality culture should be a value in the organization and be a sustainable reference of the service provider. 6) Creating automating quality. Automation has the potential to solve the problem of service quality variability caused by the lack of human resources owned by the organization. Before automating, service providers are required to review what aspects require hand touch (high touch) and elements that require automation (high tech). 7) Follow up on the service. Follow-up of services provided is necessary to further improve the unsatisfactory aspects of the service and maintain or improve aspects of the service that are already good. the way that is done by figuring out the level of satisfaction and perception of customers to the quality of services they receive. 8) Develop quality information system service. The development of service information systems encourages the systematic integration of the entire service process to continuously improve and also improve the quality of services. An important aspect of this system is its base on digging and understanding what customers want from their experience getting the service. So that the service provider is able to continue to meet customer expectations optimally.

Measuring customer satisfaction with the services provided by the government becomes an activity conducted the most in several countries. This is done to ensure that the services provided by the government are not solely to achieve the administrative objectives of the organization, but rather to the fulfillment of the needs and preferences of citizens (Howard; 2010:66).

According to Denhardt \& Denhardt, the New Public Service approach is more simply based on four concepts that are the ideas of the New Public Service, the four concepts in question are (1) democratic citizenship theory, (2) community and civil society models, (3) new humanism and public administration organizations, and (4) postmodern public administration. This concept then gives a different view in formulating the New Public Service approach (Wicaksono, 2018:26).

The Government of Indonesia itself since 2004 already has regulations related to measuring public satisfaction with services provided by government agencies. Until now there have been three changes related to the measurement of community satisfaction. The change was made in line with technological advances and increasing public demands on the quality of services.

The latest regulation governing the measurement of public satisfaction is Permenpan-RB No. 14, 2017. There are nine minimum elements that form the basis of the measurement of the public satisfaction index in this regulation. These elements are considered relevant, valid and reliable to be used as variables to know the performance of the service unit. These service elements include service procedures, service requirements, service speed, service suitability, service officer capabilities, courtesy and friendliness of officers, fairness of service costs, service facilities and infrastructure, and handling of public complaints.

According to Tjiptono, if associated with the phenomenon of customer satisfaction from the perspective of psychology, there is a view called Contrast Theory introduced by Muzafer Sherif, Daniel Taub, and Carl I. Hovland which presents the view of the consumer evaluation process after the use of a product or service that causes prediction results contrary to performance to customer satisfaction. This phenomenon magnifies between expectations and product/service performance. That is, if the performance exceeds expectations, then the consumer will feel very satisfied and vice versa if the product performance is below expectations, then the consumer is very dissatisfied (Yulia, 2018:519).

To get the community response to the quality of services provided, the method used in measuring community satisfaction in accordance to Permenpan-RB No. 14, 2017 is a survey. By using the survey method directly to service users, it will be obtained an aggregated index that represents overall community satisfaction and the results can be more accounted for methodologically (Howard; 2010:66).

As for the health sector, Kalaja, Myshketa \& Scalera (2016:558) concluded that customer satisfaction conditions can be measured through two types of service quality, namely technical and functional quality. However, from their explanation it can be known that functional quality measurements are more likely to be performed than technical quality measurements. Functional quality describes customer satisfaction with the health services provided to patients, while technical quality is performed to measure the accuracy of medical diagnoses and actions given to patients. Therefore, measuring customer satisfaction by looking at technical qualities is considered more difficult to do because the lack of patient knowledge regarding the accuracy of 
medical diagnoses and actions.

With various views of experts on the importance of innovation in services to continuously improve the degree of customer satisfaction is then began to think about how to make services, especially in the realm of public services in the field of health can meet the wishes of the public users of health services. Reorganization of the concept of public services is currently the main theme in the discussion of improving bureaucratic performance. The rapidly growing flow of information is causing people to assess the public services they critically receive. To be able to achieve the level of customer satisfaction through the services provided, it is necessary to make new breakthroughs in public services in the form of innovations (Hilda, 2009).

Given the high public demands and the need to realize the best quality of public services, the concept of rapid innovation cycle, used in the study of McCoy, Chagpar, \& Tasic (2012), can be used to produce innovations amid limited resources and time. The rapid innovation cycle consists of four stages, that are opportunity recognition, solution selection, market experimentation, and experimental results.

\section{Method}

\subsection{Research method}

This research is explorative research. The survey that has been done used a quantitative approach method with Likert Scale measurement. On the Likert scale, respondents were asked to determine their agreement level on a statement by choosing one of the available answer choices. The answer choices were divided into 4 categories i.e., from $1=$ poor to $4=$ excellent.

The execution of this Customer Satisfaction Survey (CSS) was held in two stages. The first stage was held on May - June 2019 to examine public satisfaction in the beginning and also the reference to design innovation programs as a follow-up the public service improvement. The mapping of these innovations is produced through the rapid innovation cycle concept approach. Hereafter, the second stage was held on October - November 2019 to measure public satisfaction after short-term public service innovations were implemented. The purpose of this short-term innovation program implementation was to deliver quick wins to the public and to raise confidence in the public service providers.

The scope of CSS includes entity written on Ministerial Regulation of the Empowerment of State Apparatus and Bureaucratic Reform Number 14, 2017 (Permenpan-RB No. 14/2017) concerning the Guidelines for Customer Satisfaction Survey for Public Service Providers that involves 9 elements of service value, namely, Requirements; System, Mechanism, and Procedure; Service Completion Time; Budget; Product Specification Type; Officer Competence; Officer Behaviour; Complaints Handling, Suggestions, and Feedback; and Facilities and Infrastructure

\subsection{Determining the number of respondents}

The research was conducted at Puskesmas that has a large coverage of services to the public in Bontang City. Those are Puskesmas Bontang Selatan 1 (BS 1), Puskesmas Bontang Selatan 2 (BS 2), Puskesmas Bontang Utara 1 (BU 1), and Puskesmas Bontang Utara 2 (BU 2). The number of samples is determined proportionally by using the formula from Krejcie and Morgan. The total sample target is 1,449, with details of BS 1 (364), BS 2 (340), BU 1 (372), and BU 2 (373). 1,449 are the sample targets both on phase 1 (May - June) and phase 2 (October - November). The respondents who filled out the questionaire were those who had managed or received public services (Table 1). 


\begin{tabular}{|c|c|c|c|c|c|c|}
\hline & \multicolumn{2}{|r|}{ Description } & BS1 & $\mathrm{BS} 2$ & BU1 & BU2 \\
\hline \multicolumn{7}{|c|}{ Gender: } \\
\hline & & -Male & $104(29 \%)$ & $91(27 \%)$ & $91(24 \%)$ & $151(40 \%)$ \\
\hline & & -Female & $260(71 \%)$ & $249(73 \%)$ & $281(76 \%)$ & $222(60 \%)$ \\
\hline \multicolumn{7}{|c|}{ Last education: } \\
\hline & & -Primary school & $28 \%$ & $22 \%$ & $25 \%$ & $26 \%$ \\
\hline & & -Middle school & $16 \%$ & $13 \%$ & $17 \%$ & $18 \%$ \\
\hline & & -High school & $45 \%$ & $58 \%$ & $49 \%$ & $48 \%$ \\
\hline & & -Bachelor & $11 \%$ & $8 \%$ & $8 \%$ & $7 \%$ \\
\hline & & -Master/ Doctor & $0 \%$ & $0 \%$ & $0 \%$ & $0 \%$ \\
\hline \multicolumn{7}{|c|}{ Profession: } \\
\hline & & -Civil servants & $1 \%$ & $3 \%$ & $1 \%$ & $0 \%$ \\
\hline & & -Private employee / self- & $32 \%$ & $33 \%$ & $31 \%$ & $58 \%$ \\
\hline & & employed & $2 \%$ & $4 \%$ & $2 \%$ & $2 \%$ \\
\hline & & $\begin{array}{l}\text {-Student } \\
\text { - others }\end{array}$ & $66 \%$ & $60 \%$ & $65 \%$ & $39 \%$ \\
\hline \multicolumn{7}{|l|}{ Age: } \\
\hline- & $<30$ & & $26 \%$ & $31 \%$ & $25 \%$ & $27 \%$ \\
\hline- & $30-40$ & & $25 \%$ & $29 \%$ & $28 \%$ & $26 \%$ \\
\hline- & $41-50$ & & $24 \%$ & $24 \%$ & $26 \%$ & $25 \%$ \\
\hline- & $>50$ & & $26 \%$ & $17 \%$ & $21 \%$ & $21 \%$ \\
\hline
\end{tabular}

\subsection{Data processing}

Each element of survey question ( 9 elements of service) was given a value. Each of the elements of service has equal weight. Due to the 9 elements of service, so the value of the weight is 0.11 . To obtain the value of CSS for the service unit, the weighted average value approach is used. The formula is dividing the total of perception value each element with total elements filled then multiply by weighting value (0.11).

To simplify the interpretation of CSS, the assessment result was converted with the basic value 25 (CSS value multiplied by 25). The result of the converted CSS was compared with the Interval Value Table to obtain the assessment result of the service quality and the performance, as shown in table 2.

The high target of quality and performance from CSS value (Table 2) will encourage the public service unit motivation to provide excellent services (effective, efficient, fast, safe, fair, and comfortable) and suits the needs of the customers. On the other hand, the high target of CSS value will encourage changes in bureaucratic style in serving the public to be more customer-satisfaction oriented.

Table 2 . The interval value, conversion interval value, service quality, and service unit performance

\begin{tabular}{cccc}
\hline Interval Value & Conversion Interval Value & Service Quality & Service Unit Performance \\
\hline $1.00-2.5996$ & $25.00-64.99$ & $\mathrm{D}$ & Poor \\
$2.60-3.064$ & $65.00-76.60$ & $\mathrm{C}$ & Low \\
$3.0644-3.532$ & $76.61-88.30$ & $\mathrm{~B}$ & Good \\
$3.5324-4.00$ & $88.31-100.00$ & $\mathrm{~A}$ & Very Good \\
\hline
\end{tabular}

Source: Permenpan-RB No. 14/ 2017

\section{Results}

The customer satisfaction level is a success indicator of public service. The greater the benefit that the public feels, the better the quality of the services provided. Otherwise, the low satisfaction indicates that public services being poor. The high or low public satisfaction of public service providers can be discovered by monitoring the customers' opinion or complaint. The evaluation and monitoring of public service quality must be transparent and accountable by each government public service unit since the quality of public service performance has broad implications in achieving public trust.

The target sample of respondents in this study can be met by distributing the demographic details in table 3 . In general, the respondents are dominated by women. In terms of education, the latter is dominated by high school education, and occupations are dominated by private employees/self-employed. Meanwhile, the age distribution of the respondents is quite even.

There are 9 types of services within Puskesmas that were being surveyed, those are Registration, General Polyclinic, Dental Polyclinic, Maternal \& Child Polyclinic, Immunization Polyclinic, TB Polyclinic, Nutrition Clinic, Pharmacy, and Laboratory. From the results of accumulated opinions result of 1,449 respondents, CSS achievements were obtained in Table 3. 
Table 3. The results of CSS phase I and II

\begin{tabular}{|c|c|c|c|c|c|}
\hline No. & Public Health Center (Puskesmas) & $\begin{array}{l}\text { CSS } 2019 \\
(\text { Phase 1) }\end{array}$ & Quality & $\begin{array}{l}\text { CSS } 2019 \\
(\text { Phase } 2)\end{array}$ & Quality \\
\hline 1 & Bontang Utara I (BU 1) & 78.51 & B & 97.30 & A \\
\hline 2 & Bontang Selatan I (BS 1) & 82.20 & $\mathrm{~B}$ & 95.93 & A \\
\hline 3 & Bontang Selatan II (BS 2) & 79.43 & B & 93.74 & A \\
\hline 4 & Bontang Utara II (BU 2) & 79.31 & $\mathrm{~B}$ & 89.68 & A \\
\hline & Average & 79.86 & $\mathrm{~B}$ & 94.16 & $\mathrm{~A}$ \\
\hline
\end{tabular}

According to the CSS general result of Phase 1 and Phase 2 in Table 3 was found that there is an increasing CSS value from 79.86 with category Good Service (B) to 94.16 with category Excellent (A). All Puskesmas experienced increasing CSS results with the highest achievement on Puskesmas BU 1, which was the lowest CSS value compared to the other Puskesmas.

This result shows that generally, the implemented innovation to improve the public service quality to a Puskesmas in Bontang City Government is successful and capable to raise the community satisfaction on the provided service. The increasing of CSS average value also indicates that innovation management as a follow-up from the public complaint on Phase 1 was improved optimally on CSS Phase 2.

However, the Bontang Government still needs to develop and upgrading the innovation continually in improving the quality of public service so that society satisfaction will increase. The improvement priority starts from optimizing the service speed even though it is in the Good category but it becomes the element with the lowest value compared to the others.

In a condition where there is a decreasing CSS value, it can be caused by several things, some of them are the innovation implementation does not go optimally as the follow-up of public complaint on the previous stage, which might be caused by a limited budget, human resource, and facility and infrastructure. Moreover, it can be caused by the decreasing of public service quality given to the community so there is a less optimal perception. Besides, it can be assumed that the public demand for better service increases. This condition needs serious attention to improve public service.

On the CSS Phase I, the public service condition on average had good perception. However, if it was analysed based on service elements of CSS, it was discovered that the public service was not in good condition (Table 4). It was also discovered that the most complained by the public about the service element of CSS was the speed service which was identified in all health centers, also the quality of facility and infrastructure got complained in 3 Puskesmas. The other elements that had good perception were complaints handling and the fees adjustment. BU2 became the Puskesmas with the most service element that needed improvement. The service user certainly hoped that all 7 service elements that still had complaints had improved immediately from the service provider.

From a deep analysis of the questionnaire on 1,449 respondents on 7 elements of service that is considered bad, it can be identified that the complaints from the respondents are relevant to the given service. First, it is related to the speedy service, the service users still complain about the long queue, the staff are not nimble enough, the doctor or staff arrival is not on schedule or late. Second, it is related to the quality of the facility and infrastructure, the service users complain about the small waiting room and limited chairs, limited air conditioners, the unclear sound from the loudspeaker, small parking lot, and also there is no supporting facility such as books.

Table 4. Value of service elements from CSS phase I

\begin{tabular}{llllll}
\hline No. & Service Elements & BS 1 & BS 2 & BU 1 & BU 2 \\
\hline U1 & Conformity Requirements & 3.11 & 3.17 & 3.01 & 3.05 \\
U2 & Service Procedure & 3.15 & 3.07 & 3.04 & 3.03 \\
U3 & Speed of Service & 2.81 & 2.85 & 2.99 & 3.02 \\
U4 & Suitability/Fairness Cost & 3.95 & 3.96 & 3.40 & 3.34 \\
U5 & Service Suitability & 3.19 & 3.01 & 3.13 & 3.04 \\
U6 & Officer Competency & 3.25 & 3.20 & 3.22 & 3.03 \\
U7 & The behavior of Service Officers & 3.18 & 3.01 & 3.17 & 3.06 \\
U8 & The handling of complaints & 3.80 & 3.29 & 3.27 & 3.99 \\
U9 & Quality of Facilities and Infrastructure & 3.18 & 3.06 & 3.06 & 3.03 \\
\hline & Average Value of Service Elements & 3.29 & 3.18 & 3.14 & 3.18 \\
\hline
\end{tabular}

Third, it is related to the service suitability, the service users complain about the information related to the suitability of the product they receive. Fourth, it is related to the requirements suitability, the service users complain about the lack of information about the requirements of the service. Fifth, it is related to staffs' behaviour, the users complain about the inpatient staff in serving patients and also the difficulty to talk to the staff. Sixth, it is related to the service procedures, the service users complain about there are no clear procedures 
so they have to go back and forth. Seventh, it is related to staff competence, the service users assess that some staff are still slow in giving service.

From all of the complaints, it is necessary to make improvements through short-term innovation ideas preparation on public service that the Puskesmas have to do. The innovation ideas contain innovative program/activity, implementation time target, the responsible person of the program/the activity. This is necessary to monitor and evaluate the program/activity development of the public service improvement optimally. There is a chosen innovation idea (Table 5) which has been calculated carefully at the Puskesmas level especially on the ease of the actualization so it does not require a large cost and resources.

Table 5. Short-term innovations as a follow-up to improving public services

\begin{tabular}{ll} 
No. & Service Elements \\
\hline 1. & Speed of Service
\end{tabular}

Public Service Innovations

1. Speed of Service Using SMS/ WhatsApp for registration. The procedure for registration is informed on social media, YouTube, Facebook and TV at the Health Center Promotion

Display service standards in each service unit with an eye-catching display and officers explain related service standards on the side-lines of service

Improvements of Standard Operational Procedure (SOP) to speed up the service process

Signing commitments by service officers to implement SOP and service standard

2. Quality of The arrangement of service waiting rooms, including painting/installation of

Facilities and wallpaper, provision of reading corners, and nursing rooms, the addition of waiting

Infrastructure chairs and air conditioners, sound system improvements, and dismantling of some room dividers to expand service rooms

Parking arrangement, separation of 2 wheels and 4 wheels and installation of CCTV

3. Service Provide officers with special clothing that can give a full explanation of the product, Suitability, $\quad$ requirements and service procedures for service users

Suitability $\quad$ To conduct socialization and publication service standards in public spaces with an Requirements \& eye-catching display

Procedures $\quad$ To optimize social media, YouTube, Facebook, and TV Promoting Health Center for socialization and publication of Service Standards

4. The behavior of Excellent service training

Service Officers Strengthening employee integrity in the form of leadership motivation and routine evaluation through a coffee morning

Selection of the best service personnel

5. Officer To Increase staff competency through the process of sharing knowledge among Competency

To carry out staff capacity building training such as excellent service and training in
competency gaps
$\begin{aligned} & \text { Provide assistance (mentoring and coaching) for new officers to better understand } \\ & \text { their duties }\end{aligned}$

To produce the innovation tabulation in table 5, adaptation of the rapid innovation cycle concept was carried out into four stages. The first stage is known as the opportunity recognition phase, where at this stage an effort is made to map the problems that arise in each dimension of public services, then brainstorm innovative ideas by seeing problems as opportunities. The next stage is solution selection, which is choosing the innovation that will be realized by looking at the time and available resources. the third stage is market experimentation, or the application of selected innovations in each dimension of public service for approximately four months. Then the last stage is experimental results, to see the impact of the innovations carried out, and the easiest measure or approach to determine the success of these innovations is to re-measure public satisfaction with all dimensions of public services previously received.

Several other quantitative studies have also found that service innovation has a positive effect on service user satisfaction (Mahmoud, Hinson, \& Anim., 2018; Daragahi, 2017; Utami \& Wartini, 2015; Saddique, Hayat, \& Abbas., 2013; Nemati, Khan, \& Iftikhar., 2010).

Some breakthrough is closely related to the availability of the service standards that become references to the service provider in giving service to the public. The service standard component that must be known by the public at least is the service delivery component that consists of six elements, which are requirement, procedure, a period of time, cost, product, and complaint handling management. This service standard becomes an innovation target from some service elements which require improvement.

The public service improvement innovation is then followed up by the action of change by all Puskesmas. Innovation in Table 5 is the early innovation which is short-term and relatively does not require a lot of resources so that the impact and the achievement will be seen immediately and measured. Nonetheless, the other 
innovation which is the medium term and long term are still identified as a plan and public service improvement program at the Puskesmas level for the future.

After the implementation of the innovation less in 4 months, the next step is surveying the customer satisfaction phase 2. The analysis result on 9 elements of service forming CSS phase 2 has been done that is shown in Table 6. The result is all of the service elements are in a Good category and Excellent category. The perception of the service users evenly gave positive feedback and showed that the Service Unit's effort is optimal enough to encourage increased community satisfaction. The complaints from the service users were also not found since the short-term innovation effort was implemented. It is different from the condition in CSS Phase I can be seen in Table 4.

Table 6. Value of service elements of CSS phase 2

\begin{tabular}{llllll}
\hline No. & \multicolumn{1}{c}{ Service Elements } & BS 1 & BS 2 & BU 1 & BU 2 \\
\hline U1 & Conformity Requirements & 3.78 & 3.77 & 3.85 & 3.63 \\
U2 & Service Procedure & 3.80 & 3.75 & 3.87 & 3.58 \\
U3 & Speed of Service & 3.66 & 3.50 & 3.74 & 3.11 \\
U4 & Suitability/ Fairness Cost & 3.99 & 4.00 & 3.99 & 3.84 \\
U5 & Service Suitability & 3.85 & 3.57 & 3.88 & 3.63 \\
U6 & Officer Competency & 3.88 & 3.87 & 3.95 & 3.60 \\
U7 & The behavior of Service Officers & 3.83 & 3.64 & 3.91 & 3.63 \\
U8 & The handling of complaints & 3.99 & 3.99 & 3.99 & 3.84 \\
U9 & Quality of Facilities and Infrastructure & 3.80 & 3.68 & 3.88 & 3.46 \\
\hline & Average Value of Service Elements & 3.84 & 3.75 & 3.90 & 3.59 \\
\hline
\end{tabular}

\section{Discussions}

This research purpose is to measure the quality of Puskesmas in Bontang City through CSS that was held in 2 stages and used the complaints from the service users as the basis to do some innovations and improvements in service quality. The chosen innovation was the quickly realized one, gave a direct impact on service users, also solved the problems that were complained about by the community. The result showed increasing public satisfaction. The implemented innovation increased the public trust in the government and also increased the service providers' confidence. This achievement still needs encouragement and development.

Innovation is the key to give a significant difference in a routine condition encountered. Innovation source can be from a problem faced by the organization, and the biggest problem source was found from the users' complaints and feedback. As stated by Ueki \& Martinez (2019) that a problem can be considered a source of knowledge to innovate. Furthermore, all the complaints and feedback relevance needed to be inventoried with the given service. The related feedback can be classified based on the existing service element and then all the service management discussed the innovation ideas. The innovation ideas then needed to be compared to the availability of the existing source so that there will be a priority list about the innovation that soon will be implemented.

Therefore, public service providers need to manage the problems raised by the public as part of improving service quality and public satisfaction. The ability to identify problems and solve problems with innovation will be an important combination in managing perfect service for public satisfaction. If it can be implemented optimally, every public service will provide a new experience for its users.

In the public service context, the service users tend to wanting a quick result or wanting to see the change immediately, so that choosing an innovation context that can be actualized in short term will fulfill public satisfaction immediately. The public can immediately feel there is a change and gain a different experience when dealing with public service and hopefully can spread to all service users so the positive image will be formed on the given service. In the middle of the technology advances, information about the success of public service can easily spread by using digital technology such as social media.

Furthermore, in order to implement the innovation effectively and continuously, Bontang City Government needs to be committed to supporting the innovation effort in public service improvement through strengthening policies needed starts from regulation policy, budgeting, human resources, information, and technology system, up to the supporting facilities and infrastructure of the public service. Giving an appreciation to the public service provider can be implemented to encourage the quality of public service improvement and innovation. This is in accordance with a study conducted by Rajapathirana \& Hui (2018) which states that innovative abilities apart from depending on employee creativity, are also closely related to the organizational culture that supports innovation.

\section{Conclusion}

This research was qualitatively analyzing the community satisfaction level in four public health centers 
(Puskesmas) in Bontang City. The method used was two stages of the survey on 1.449 respondents in 2019 and used the service users' complaints as the basis to implement innovation to improve the public service. Customer satisfaction before and after the innovation showed a significant enhancement. The innovation was short-term obtained from the effort to respond to complaints and feedback from the public on the service condition given by Puskesmas. The most complained elements by the public are the service speed and the quality of facility and infrastructure. The increasing customer satisfaction on the public service element became indicators to enhance the quality of the public service.

Based on the results of these studies, theoretical and practical implications can be stated. The theoretical implication provides the view that problems that arise and are disclosed transparently by the public in public services can be used as the basis for generating ideas or ideas for implementing public service innovations. The involvement of service users and all public service implementing officers to share ideas and innovative ideas will facilitate strengthening the quality of services provided to increase service user satisfaction. Thus, innovation becomes an important activity that will affect service user satisfaction.

The practical implications of the results of this study are useful for the agency of the public service to foster innovation by using the feedback and complaints from the service users. The perception that says that innovating is quite difficult to do in the public sector can be overcome by methods and processes as in this study. Innovation needs to be promoted as a culture, and a leader's commitment is needed to create a climate of innovation that supports it.

The limitations of this research, which then can be used as the basis for further research, are: first, the time was too short between the survey and the innovation implementation which were planned. Second, the innovation result did not pass the trial process and was immediately executed. The next execution, simulation, or trial needs to be done first by involving the community representation to get feedback to strengthen the innovation. Third, it needs to calculate the innovation that can be implemented not only for the short-term but also for the medium term and long term in the form of a road map of innovation to increase public service quality.

\section{Acknowledgments}

The authors would like to thanks the Organizational Section-Bontang City Government and Centre for Training and Development and Decentralization and Regional Autonomy Studies-National Institute of Public Administration (Puslatbang KDOD LAN) for the cooperation in the customer satisfaction survey. Besides that, we also appreciate the support from STITEK Bontang and Trunajaya University in Bontang City that helped to collect respondent's data.

\section{References}

Ahmed, S., Tarique, K. M., \& Arif, I. (2017). Service quality, patient satisfaction and loyalty in the bangladesh healthcare sector. International Journal Of Health Care Quality Assurance, 30(5), 477-488. https://doi.org/10.1108/IJHCQA-01-2017-0004.

Akinboade, O. A., Kinfack, E. C., \& Mokwena, M. P. (2012). An analysis of citizen satisfaction with public service delivery in the sedibeng district municipality of south africa. International Journal of Social Economics, 39(3), 182-199. https://doi.org/10.1590/1807-7692bar2015140082.

Antanegoro, RM Yordan., Surya, Djasuro., \& Sanusi, Fauzi. (2017). Analisis pengaruh inovasi produk, inovasi layanan dan kualitas pelayanan terhadap kepuasan dan loyalitas nasabah. Jurnal Riset Bisnis dan Manajemen Tirtayasa, 1(2), 167-178.

Bamfo, B. A., \& Dogbe, C. S. K. (2017). Factors influencing the choice of private and public hospitals: empirical evidence from Ghana. International Journal of Pharmaceutical and Healthcare Marketing, 11(1), 80-96. https://doi.org/10.1108/17506121211216905.

Chatzoglou, P., Chatzoudes, D., Vraimaki, E., \& Diamantidis, A. (2013). Service quality in the public sector: The case of the Citizen's Service Centers (Cscs) of Greece. International Journal of Productivity and Performance Management, 62(6), 583-605. https://doi.org/10.1108/IJPPM-12-2012-0140.

Denhardt, Janet V. \& Denhardt, Robert B. (2000). The new public service: serving rather than steering. Article in Public Administration Review, DOI: 10.1111/0033-3352.00117.

Dwiyanto, Agus. (2015). Reformasi birokrasi kontekstual. Yogyakarta: Gadjah Mada Unversity Press.

Fahamsyah, D. (2018). Pengukuran Indeks Kepuasan Masyarakat (IKM) pelayanan kesehatan di puskesmas Kabupaten Hulu Sungai Utara. Jurnal Administrasi Kesehatan Indonesia, 6(2), 189. https://doi.org/10.20473/jaki.v6i2.2018.189-196.

Ghotbabadi, A. R., Feiz, S., \& Baharun, R. (2015). Service quality measurements: A review. International Journal of Academic Research in Business and Social Sciences, 5(2), 267-286. https://doi.org/10.6007/IJARBSS/v5-i2/1484.

Graham, J. L. (1986). The problem-solving approach to negotiations in industrial marketing. Journal of Business 
Research, 14(6), 549-566. https://doi.org/10.1016/0148-2963(86)90014-7.

Haryani, T. N., Ambarwati, O. C., Kusumastuti, N., \& Nurwijayanti, A. A. (2017). The challenge to the innovation of complaint mechanism from mobile to it-based complaint mechanism. Kne Social Sciences, 2(4), 229-235. https://doi.org/10.18502/kss.v2i4.891.

Hidayati, R., \& Novani, S. (2015). A conceptual complaint model for value co-creation process. Procedia Manufacturing, 4(Iess), 412-418. https://doi.org/10.1016/j.promfg.2015.11.057.

Hilda, Nurul. (2014). Strategi inovasi layanan dalam meningkatkan kualitas pelayanan di kantor pertanahan Kota Surabaya II. Jurnal Kebijakan dan Manajemen Publik, 2 (1), Januari 2014. ISSN 2303-341X

Hoflinger, P.J., Nagel, C., \& Sandner, P. (2018). Reputation for technological innovation: Does it actually cohere with innovative activity? Journal of Innovation \& Knowledge, 3(1), 26-39. https://doi.org/10.1016/j.jik.2017.08.002

Howard, C. (2010). Are we being served? A critical perspective on canada's citizens first satisfaction surveys. International Review of Administrative Sciences, 76(1), 65-83. https://doi.org/10.1177/0020852309359045

Irfan, S. M., Ijaz, A. (2011). Comparison of service quality between private and public hospitals: Empirical evidences from Pakistan. Journal of Quality and Technology Management, 13(2), 115-127. https://doi.org/10.1177/1745790413488777

Jason Huang, H., \& Dastmalchian, A. (2006). Implications of trust and distrust for organizations: Role of customer orientation in a four-nation study. Personnel Review, 35(4), 361-377. https://doi.org/10.1108/00483480610670553

Javed, S. A., \& Ilyas, F. (2018). Service quality and satisfaction in healthcare sector of Pakistan-The patients' expectations. International Journal Of Health Care Quality Assurance, 31(6), 489-501. https://doi.org/10.1108/IJHCQA-08-2016-0110

Kalaja, R., Myshketa, R., \& Scalera, F. (2016). Service quality assessment in health care sector: The case of Durres Public Hospital. Procedia - Social and Behavioral Sciences, 235(October), 557-565. https://doi.org/10.1016/j.sbspro.2016.11.082

Keh, H. T., Nguyen, T.T.M., \& Ng, H.P. (2007). The effects of entrepreneurial orientation and marketing information on the performance of SMEs. Journal of Business Venturing, 22(4), 592-611. https://doi.org/10.1016/j.jbusvent.2006.05.003

Khan, M. B., Batool, I., Scholar, M., \& Hussain, S. (2015). Customer satisfaction at public sector : A case study of Pakistan Housing Authority. Pakistan Journal of Social Sciences, 35(2), 1037-1050.

McCoy, Chris D., Chagpar, Zubin., \& Tasic, Igor. (2012). The Rapid Innovation Cycle-An innovation and market testing process for new products and services development. Conference Paper ASEAN-November 2012. Retrieved from https://www.researchgate.net/publication/234066207

Mouwen, A. (2015). Drivers of customer satisfaction with public transport services. Transportation Research Part A: Policy And Practice, 78, 1-20. https://doi.org/10.1016/j.tra.2015.05.005

Muslimin B Putra. (2020). Pengukuran kepuasan masyarakat. Retrieved February 13, 2020, From Ombudsman, Website: https://ombudsman.go.id/Artikel/R/Artikel--Pengukuran-Kepuasan-Masyarakat.

Ombudsman RI. (2019). Hasil penilaian kepatuhan terhadap standar pelayanan dan kompetensi penyelenggara pelayanan sesuai Undang-Undang Nomor 25 Tahun 2009 tentang pelayanan publik. 5. Retrieved February 13, 2020, From Ombudsman, Website: https://ombudsman.go.id/produk/?c=19\&s=LP

Parasuraman, A., Zeithaml, V. A., \& Berry, L. L. (1985). A conceptual model of service quality and its implications for future research. Journal of Marketing, 49(4), 41-50. https://doi.org/10.2307/1251430

Parobek, Jan., Loučanová, Erika., Kalamárová, Martina., Šupin, Mikuláš., \& Štofková, Repková Katarina. (2015). Customer window quadrant as a tool for tracking customer satisfaction on the furniture market. Procedia Economics and Finance, 34 (2015), 493 -499

Rajapathirana, R.J., \& Hui, Y. (2018). Relationship between innovation capability, innovation type, and firm performance. Journal of Innovation \& Knowledge, 3(1), 44-55. https://doi.org/10.1016/j.jik.2017.06.002

Savitri, M., \& Armando, D. Y. (2019). A survey on the community satisfaction index based on Kepmenpan No. 25/M.PAN/2/2004 at Kanujoso Djatiwibowo Regional General Hospital, Balikpapan in 2018. Journal of Indonesian Health Policy and Administration, 4(1), 22-26. https://doi.org/10.7454/ihpa.v4i1.2855

Simmons, R., \& Brennan, C. (2017). User voice and complaints as drivers of innovation in public services. Public Management Review, 19(8), 1085-1104. https://doi.org/10.1080/14719037.2016.1257061

Siregar, F., Usmani, M. L., Kumaralalita, L., Nufaisa, H., \& Putri, D. A. (2017). Complaining to improve governance: four stories of complaint-handling systems in Indonesia. (February 2017). Retrieved From http://cipg.or.id/wp-content/uploads/2017/03/MAVC_CIPG_Pr3Final_WEB.pdf

Solong, H. Aras. (2017). Actualization new public service (NPS) administration in public service. International Journal of Scientific and Research Publication, 7 (3), March 2017. ISSN 2250-3153

Tjiptono, Fandy., \& Chandra, Gregorius. (2005). Service, quality, \& satisfaction. Yogyakarta: Penerbit Andi. ISBN 979-731-609-2 
Ueki, Yasushi., \& Martinez, Jose Manuel G. (2019). The impact of engineers' skill and problem-solving abilities on process innovation. Economic Research-Ekonomska Istraživanja, 33(1), 2018-2037. https://doi.org/10.1080/1331677X.2019.1596826

Wicaksono, K.W. (2018). Transforming the spirit of new public service into public management reform in Indonesia. Jurnal Manajemen Pelayanan Publik, 2(1), 24-33. doi:https://doi.org/10.24198/jmpp.v2i1.20190

Yaşlioğlu, M., Çalişkan, B. Ö. Ö., \& Şap, Ö. (2013). The Role of innovation and perceived service quality in creating customer value: A Study on employees of a call center establishment. Procedia - Social And Behavioral Sciences, 99 (November), 629-635. https://doi.org/10.1016/j.sbspro.2013.10.533

Yoon, Cheolho. (2010). Antecedents of customer satisfaction with online banking in China: The effects of experience. Computers in Human Behavior, 26 (2010), 1296-1304

Yulia, N. (2018). Hubungan antara kualitas pelayanan dengan kepuasan pelanggan. Prosiding Manajemen Komunikasi, 4(2), 517-523. doi:http://dx.doi.org/10.29313/.v0i0.11945 